\title{
PENGARUH SIKAP YANG BAIK, INTEGRITAS, LOYALITAS DAN KEPERCAYAAN TERHADAP SUKSESI PADA BISNIS KELUARGA BERBASIS FAMILY OWNED ENTERPRISE (FOE) GENERASI PERTAMA
}

\author{
Brendi Wijaya $^{1}$, Andreas Wijaya ${ }^{2}$ dan Renaldy Kurniawan ${ }^{3}$ \\ ${ }^{1)}$ Program Studi Manajemen, Universitas Bunda Mulia
}

\begin{abstract}
This study aims to determine the succession planning that will be done on family-based company. Family Owned Enterprise (FOE). Subjects In this study used 3 companies that are large-scale enterprises, companies in the medium scale, and companies on a small scale. The company is used as a research subject because this family oriented bussines will face the first succession planning process to a successor candidate who is not from a family member. The purpose of this study is to know in further examine the factors in succession to prospective successors who are not from family members.
\end{abstract}

Keywords: Succession, Family Oriented Business

\begin{abstract}
ABSTRAK
Penelitian ini bertujuan untuk mengetahui perencanaan suksesi yang akan dilakukan pada perusahaan keluarga berbasis Family Owned Enterprise (FOE). Subyek Pada penelitian ini menggunakan 3 perusahaan yang merupakan perusahaan dalam skala besar, perusahaan dalam skala menengah, dan perusahaan dalam skala kecil. Perusahaan ini digunakan sebagai subyek penelitian karena perusahaan keluarga ini bersifat (family oriented bussines) akan menghadapi proses perencanaan suksesi pertama kalinya ke calon suksesor yang bukan berasal dari anggota keluarga. Tujuan dari penelitian ini adalah untuk mengetahui dalam menelaah lebih jauh faktor dalam suksesi ke calon suksesor yang bukan berasal dari anggota keluarga.
\end{abstract}

Keyword: Suksesi, Family Oriented Bussines

\footnotetext{
Korespondensi Penulis

Email:

bwijaya@bundamulia.ac.id

awijaya@bundamulia.ac.id
} 


\section{PENDAHULUAN}

Kewirausahaaan merupakan awal dari terbentuknya usaha keluarga (Poza, 2007), ketika pemilik mengajak anaknya untuk berpartisipasi dalam usaha, maka kewirausahaan dapat berkembang menjadi bisnis yang beorientasi pada keluarga. Maka dapat dilihat peranan bisnis keluarga tidak terlepas dari hubungan keluarga dari pemilik dan anggotanya. Namun faktanya masalah yang sering terjadi justru dalam kelanggengan usaha, mengacu dari hasil temuan Beckhard dan Dyer (1983). Statistik menunjukkan keputusan antara keyakinan optimis pemilik bisnis keluarga saat ini dan realitas kegagalan besar perusahaan keluarga untuk bertahan hidup dari generasi ke generasi.

Untuk mempertahankan kelanggengan usaha dalam bisnis keluarga, beberapa peneliti meyakini untuk menekankan suksesi dalam bisnis keluarga (Barnes dan Hershon, 1989; Schein, 1983; Levinson, 1983). Kets De Vries (1985) juga menyatakan bahwa tiga dari sepuluh perusahaan keluarga dapat bertahan hingga ke generasi kedua. Namun, hanya terdapat satu dari sepuluh perusahaan keluarga yang bisa bertahan hingga ke generasi ketiga. Sulitnya untuk mempertahankan bisnis dari generasi pertama hingga ke generasi ketiga dapat disebabkan oleh beberapa hal antara lain Pengalaman kerja dan pendidikan yang berlawanan, bayang-bayang generasi pertama, karakteristik generasi penerus yang kurang memiliki daya juang, nepotisme lingkungan kerja, kurangnya kepercayaan pada profesional non keluarga.

Melihat berbagai fenomena yang terjadi, keberhasilan suksesi tidak dapat dikatakan mudah, karena untuk mempersiapkan calon suksesor dibuthkan proses dan waktu sampai dengan yang tidak ditentukan agar calon suksesor menjadi siap (Churchill and Lewis, 1983; Farquhar, 1989; Friedman, 1991; Gilmore and McCann, 1983; Gordon and Rosen, 1981; Handler, 1990; Longenecker and Schoen, 1975, 1978; Vancil, 1987). Lansberg (1999) menyatakan suksesi generasi pertama dari pendiri bisnis, biasanya melakukan suksesi karena sudah merasa tidak kuat mengendalikan perusahaan yang disebabkan karena faktor usia. Baer (2007) dalam studinya menganalisa suksesi ke generasi ke-2 mempertimbangkan loyalitas dan kedekatan emosional antara para kadinat calon suksesor yang menjadi masalah pelik dan sulit dipecahkan. Dan bila perusahaan keluarga telah mencapai generasi ke-tiga terdapat pergeseran permasalahan yaitu apakah memilih suksesor dari dalam anggota keluarga ataukah dari luar dengan pertimbangan profesionalisme (Hall, 2008), tingkat pendidikan (Royer, 2008), kecakapan pengelolaan usaha, dan gender (Harveston, 1997). Lebih jauh, ketika terjadi permasalahan suksesi di perusahaan keluarga generasi ke-empat, kebanyakan permasalahan suksesi disebabkan oleh faktor-faktor tata nilai dari karyawan sehubungan dengan budaya perusahaan (Zulfikar, 2004).

Melihat permasalahan yang ada maka, temuan yang menarik perhatian adalah kesiapan membuat bisnis lebih profesional. Profesionalisme bisnis menjadi kekhawatiran utama perusahaan keluarga, disebabkan oleh makin ketatnya tekanan persaingan secara global, meningkatnya biaya, dan mempertahankan kelanggengan usaha. Melihat permasalahan yang ada, maka peneliti akan mengkaji lebih dalam proses sukesi kepada generasi penerus sebagai kesiapan dalam menghadapi mitos bisnis keluarga : generasi pertama mendirikan, generasi kedua membangun, generasi ketiga menghancurkan. Maka peneliti tertarik untuk menggali lebih dalam proses suksesi kepada bukan anggota keluarga, sebagai tolak ukur dari suksesi yang akan diberikan kepada anggota keluarga.

\section{TINJAUAN PUSTAKA}

\section{Binsis Keluarga}

Poza (2007) perusahaan keluarga adalah perusahaan yang kontrol kepemilikan, partisipasi manajerial, dan nilai-nilai yang dianut pendiri perusahaan atau CEO generasi dan satu atau lebih anggota keluarga berpengaruh secara signifikan terhadap perusahaan Dussault (2008), perusahaan 
keluarga adalah sebuah organisasi yang mayoritas kepemilikan lebih dari 50\% lebih oleh anggota keluarga, di mana terdapat dua atau lebih anggota keluarga yang terlibat dalam aktivitas manajemen perusahaan, dikontrol, serta akan dipimpin oleh anggota keluarga dari generasi berikutnya.

\section{Jenis Binsis Keluarga}

Dalam terminologi bisnis, terdapat dua jenis perusahaan keluarga (Susanto, 2005), yaitu Family Owned Enterprise (FOE) dan Family Business Entreprise (FBE). Perusahaan yang dimiliki oleh keluarga tetapi perusahaan tersebut dikelola oleh orang luar yang bukan merupakan anggota keluarga dimana keluarga hanya berperan sebagai pemilik dan tidak ikut aktif dalam menjalankan bisnisnya tetapi menyerahkan kepada seorang profesional di luar anggota keluarga sebagai orang yang menjalankan bisnis keluarga disebut Family Owned Enterprise (FOE), sedangkan Family Business Entreprise (FBE), yaitu perusahaan yang dimiliki dan dikelolah oleh keluarga pendirinya. Ciri-ciri perusahaan ini adalah dipegangnya posisi-posisi penting di perusahaan oleh anggota keluarga perusahaan pendiri

\section{Suksesi}

Menurut Rothwell (2010) perencanaan suksesi didefinisikan sebagai upaya yang disengaja dan sistematis oleh sebuah organisasi untuk menjamin kelangsungan kepemimpinan di perusahaan keluarga dari generasi ke generasi.

Tabel 1. Penelitian Terdahulu

\begin{tabular}{|c|c|c|c|c|}
\hline $\mathrm{NO}$ & Judul Penelitian & Pengarang & Variabel & Hasil \\
\hline 1 & $\begin{array}{l}\text { "More than } \\
\text { family : Non- } \\
\text { Family } \\
\text { Executives in } \\
\text { the Family, } \\
\text { Business" }\end{array}$ & $\begin{array}{l}\text { 1. Aronoff } \\
\text { 2. Ward }\end{array}$ & $\begin{array}{ll}\text { 1. } & \text { Integritas } \\
\text { 2. } & \text { Kepercayaan } \\
\text { 3. } & \text { Suksesi }\end{array}$ & $\begin{array}{c}\text { Calon suksesor untuk } \\
\text { non anggota keluarga } \\
\text { dilihat dari } \\
\text { integirutas, dan } \\
\text { loyalitas dari pemilik } \\
\text { kepada karyawan. }\end{array}$ \\
\hline 2 & $\begin{array}{l}\text { "Non-Family } \\
\text { CEO's in the } \\
\text { Family } \\
\text { Business : } \\
\text { Connecting } \\
\text { Family Values } \\
\text { to Business } \\
\text { Sucess" }\end{array}$ & $\begin{array}{ll}\text { 1. } & \text { Astrachan } \\
\text { 2. Keyt } \\
\text { 3. Lane } \\
\text { 4. } & \text { Yarmalouk }\end{array}$ & $\begin{array}{l}\text { 1. Loyalitas } \\
\text { 2. Suksesi }\end{array}$ & $\begin{array}{l}\text { Dalam temuannya } \\
\text { pada bisnis berbasis } \\
\text { keluarga, loyalitas } \\
\text { menjadi pertimbangan } \\
\text { untuk memberikan } \\
\text { suksesi bagi karyawan } \\
\text { non - anggota. }\end{array}$ \\
\hline 3 & $\begin{array}{l}\text { "Finding } \\
\text { Success } \\
\text { through } \\
\text { succession } \\
\text { planning. } \\
\text { Security } \\
\text { Management" }\end{array}$ & 1. Diamond & $\begin{array}{ll}\text { 1. } & \text { Loyalitas } \\
\text { 2. } & \text { Suksesi } \\
\text { 3. } & \text { Integritas }\end{array}$ & $\begin{array}{l}\text { Suksesi ditawarkan } \\
\text { kepada karyawan } \\
\text { yang ingin maju dan } \\
\text { dapat digunakan } \\
\text { untuk meningkatkan } \\
\text { produktivitas dan } \\
\text { loyalitas karyawan. }\end{array}$ \\
\hline 4 & $\begin{array}{l}\text { The Ownership } \\
\text { Trust and } \\
\text { Succession } \\
\text { Paralysis in the } \\
\text { Family } \\
\text { Business." } \\
\text { Family } \\
\text { Business }\end{array}$ & 1. McCollom & $\begin{array}{l}\text { 1. Kepercayaan } \\
\text { 2. Integritas } \\
\text { 3. Sikap yang baik } \\
\text { 4. Loyalitas }\end{array}$ & $\begin{array}{c}\text { Kepercayaan yang } \\
\text { diberikan oleh pemilik } \\
\text { perusahan } \\
\text { berdasarkan dari } \\
\text { integritas serta sikap } \\
\text { yang baik dari calon } \\
\text { suksesor sebagai } \\
\text { landasan dalam proses }\end{array}$ \\
\hline
\end{tabular}




\begin{tabular}{|c|c|c|c|c|}
\hline & Review, & & & suksesi. \\
\hline 5 & $\begin{array}{l}\text { Succession and } \\
\text { nonsuccession } \\
\text { concerns of } \\
\text { family firms } \\
\text { and agency } \\
\text { relationships } \\
\text { with nonfamily } \\
\text { managers. }\end{array}$ & $\begin{array}{l}\text { 1. Chua, } \\
\text { 2. Chrisman, J } \\
\text { 3. Sharma, P. }\end{array}$ & $\begin{array}{l}\text { 1. Sikap yang baik } \\
\text { 2. Loyalitas } \\
\text { 3. Suksesi }\end{array}$ & $\begin{array}{c}\text { Pemimpin perusahaan } \\
\text { melihat suksesi dari } \\
\text { loyalitas melalui sikap } \\
\text { yang baik yang } \\
\text { dimiliki karyawan. }\end{array}$ \\
\hline 6 & $\begin{array}{l}\text { Professional } \\
\text { Management in } \\
\text { Family } \\
\text { Businesses: } \\
\text { Toward an } \\
\text { Extended } \\
\text { Understanding. }\end{array}$ & $\begin{array}{ll}\text { 1. Hall, } \\
\text { 2. Anika, } \\
\text { 3. Mattias } \\
\text { 4. Nordqvist. }\end{array}$ & $\begin{array}{ll}\text { 1. } & \text { Integritas } \\
\text { 2. } & \text { Loyalitas } \\
\text { 3. } & \text { Suksesi }\end{array}$ & $\begin{array}{c}\text { Pemimpin perusahaan } \\
\text { mempertimbangkan } \\
\text { pemberian suksesi } \\
\text { kepada non-anggota } \\
\text { keluarga apabila } \\
\text { melihat adanya } \\
\text { loyalitas yang tinggi } \\
\text { dan integritas yang } \\
\text { baik dari karyawan. }\end{array}$ \\
\hline
\end{tabular}

\section{Hipotesis Penelitian}

Ha1: Terdapat pengaruh yang signifikan dari variabel Sikap yang baik terhadap variabel Loyalitas.

Ha 2 : Terdapat pengaruh yang signifikan dari variabel Sikap yang baik terhadap variabel Kepercayaan.

Ha3 : Terdapat pengaruh yang signifikan dari variabel Integritas terhadap variabel Loyalitas.

Ha 4 : Terdapat pengaruh yang signifikan dari variabel Intgritas terhadap variabel Kepercayaan.

Ha5 : Terdapat pengaruh yang signifikan dari variabel Loyalitas terhadap variabel Suksesi.

Ha 6 : Terdapat pengaruh yang signifikan dari variabel Kepercayaan terhadap variabel Suksesi.

\section{METODE PENELITIAN}

\section{Prosedur Penelitian}

Penelitian ini menggunakan Subyek Pada penelitian ini yaitu para pelaku bisnis usaha yang bersifat Family Owned Enterprise (FOE) akan menghadapi proses perencanaan suksesi kepada non anggota keluarga. Obyek Penelitian Menurut Sugiyono (2012) adalah suatu nilai, sifat atau atribut dari orang, objek kegiatan yang mempunyai variasi tertentu yang ditetapkan untuk dipelajari kemudian ditarik esimpulannya. Di dalam penelitian ini, objek penelitiannya adalah proses perencanaan suksesi di perusahaan yang terdiri dari : sikap, integritas, loyalitas, kepercayaan, dan suksesi.

\section{HASIL DAN PEMBAHASAN}

\section{Profil Responden}

Populasi dalam penelitian ini adalah seluruh pemilik usaha berbasis FOE di Jakarta. Instrumen yang digunakan dalam penelitian ini berupa kuesioner yang disebarkan dengan menggunakan media google docs. Total kuesioner yang terisi adalah sebanyak 92 kuesioner. 
Tabel 2. Profil Responden

\begin{tabular}{|c|c|c|c|}
\hline No & Profil & Kategori & $\begin{array}{c}\text { Persentase } \\
(\%)\end{array}$ \\
\hline \multirow{2}{*}{1} & \multirow{2}{*}{ Gender } & Pria & 52.2 \\
\hline & & Wanita & 47.8 \\
\hline \multirow{4}{*}{2} & \multirow{4}{*}{ Usia } & $\begin{array}{l}20-30 \\
\text { Tahun }\end{array}$ & 78.3 \\
\hline & & $\begin{array}{l}31-40 \\
\text { Tahun }\end{array}$ & 8.7 \\
\hline & & $\begin{array}{l}41-50 \\
\text { Tahun }\end{array}$ & 8.7 \\
\hline & & $\begin{array}{l}\text { 51-60 } \\
\text { Tahun }\end{array}$ & 4.3 \\
\hline \multirow{5}{*}{3} & \multirow{5}{*}{$\begin{array}{l}\text { Lama } \\
\text { Usaha }\end{array}$} & 1-5 Tahun & 57.3 \\
\hline & & $\begin{array}{c}\text { 6-10 } \\
\text { Tahun }\end{array}$ & 14.6 \\
\hline & & $\begin{array}{l}\text { 11-15 } \\
\text { Tahun }\end{array}$ & 12.4 \\
\hline & & $\begin{array}{l}\text { 16-20 } \\
\text { Tahun }\end{array}$ & 5.6 \\
\hline & & $>20$ Tahun & 10.1 \\
\hline
\end{tabular}

Sumber : data diolah

\section{Evaluasi Measurement (Outer) Model :}

\section{Gambar 1. Tampilan hasil PLS Algorithm}

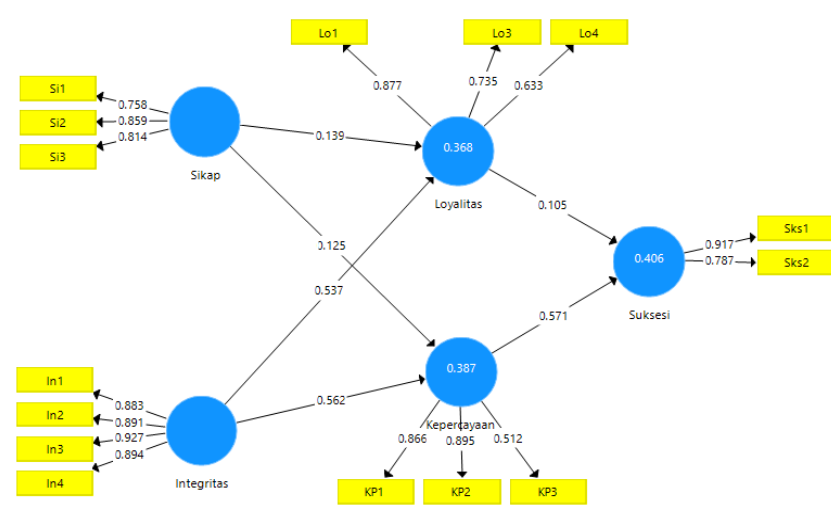

\section{Validitas Konvergen}

Tabel 3. Construct Realibility and Validity

\begin{tabular}{|c|c|c|c|c|}
\hline & Cronbach's Al... & rho_A & Composite Rel... & Average Varian... \\
\hline Integritas & 0.921 & 0.926 & 0.944 & 0.808 \\
\hline Kepercayaan & 0.665 & 0.768 & 0.813 & 0.604 \\
\hline Loyalitas & 0.624 & 0.699 & 0.796 & 0.570 \\
\hline Sikap & 0.741 & 0.753 & 0.852 & 0.658 \\
\hline Suksesi & 0.645 & 0.728 & 0.843 & 0.730 \\
\hline
\end{tabular}

Sumber : data diolah

Berdasarkan tabel 3 semua variabel dikatakan valid karena memiliki nilai AVE diatas dari 0,5 .

\section{Validitas Diskriminan}

\section{Tabel 4. Cross Loading}

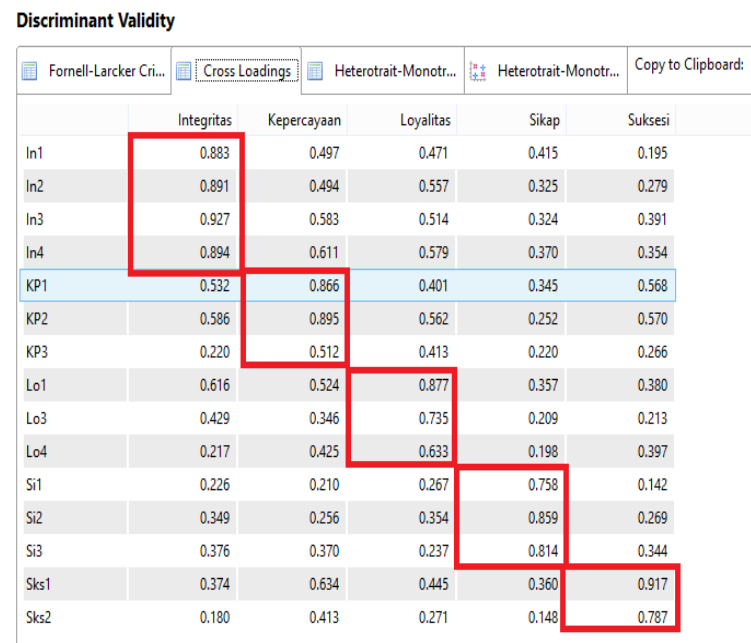

Sumber : data diolah

Berdasarkan tabel diatas dapat dilihat bahwa masing-masing variabel sudah memenuhi syarat validitas diskriminan.

Sumber : data diolah 


\section{Composite Realibility dan Cronbach's Alpha}

Tabel 5. Construct Realibility and Validity

\begin{tabular}{l|cccc} 
& Cronbach's Al... & \multicolumn{1}{c}{ rho_A } & Composite Rel.... & Average Varian... \\
\hline Integritas & 0.921 & 0.926 & 0.944 & 0.808 \\
\hline Kepercayaan & 0.665 & 0.768 & 0.813 & 0.604 \\
\hline Loyalitas & 0.624 & 0.699 & 0.796 & 0.570 \\
\hline Sikap & 0.741 & 0.753 & 0.852 & 0.658 \\
\hline Suksesi & 0.645 & 0.728 & 0.843 & 0.730
\end{tabular}

Sumber : data diolah

Variabel dapat dikatakan reliabel jika memiliki nilai composite reliability di atas 0,70 dan cronbach's alpha di atas 0,60. Dari hasil output di atas bisa dilihat nilai composite reliability di atas 0,70 dan cronbach's alpha di atas 0,60 sehingga reliabel.

\section{Pengujian Model Struktural (Inner Model)}

\section{Gambar 2. Tampilan Hasil PLS}

\section{Boothstrapping}

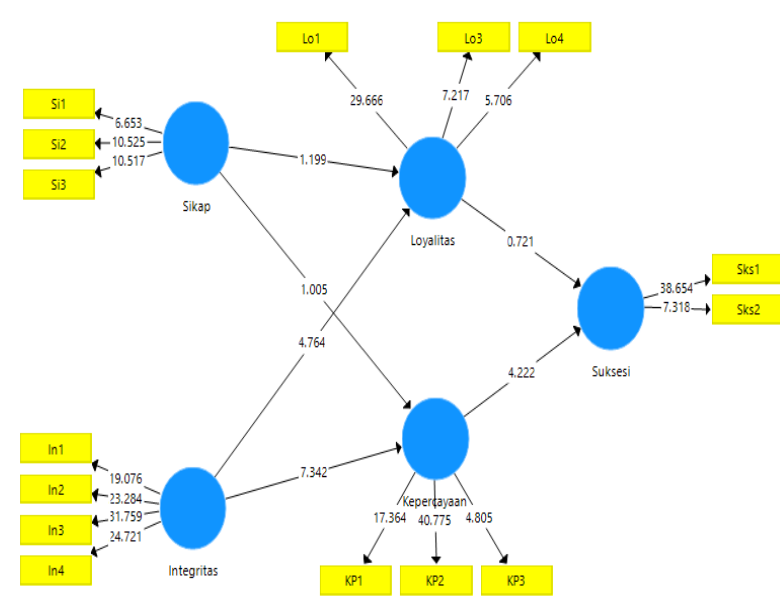

Sumber : data diolah
Tabel.6 Path Coefficients (Mean, STDEV, T Statistics)

\begin{tabular}{|c|c|c|c|c|c|c|c|c|}
\hline \multirow[t]{2}{*}{ Mean, STDEV, } & V, T-Values.. & 圆c & onfidence Intervals & Confidenc & el Intervals $B$. & & Samples & Copyto \\
\hline & \multicolumn{2}{|c|}{ Original Samp } & Sample Mean (... & Standard Devia.... & TStatistic & $c s(\mid 0 . .$. & & PValues \\
\hline Integritas $• K_{e_{\text {... }}}$ & & 0.562 & 0.564 & 0.079 & & 7,080 & & 0.000 \\
\hline Integritas $>$ L Lo.". & & 0.537 & 0.534 & 0.114 & & 4.709 & & 0.000 \\
\hline Kepercayaan -..' & & 0.571 & 0.572 & 0.133 & & 4.299 & & 0.000 \\
\hline Loyalitas -> Su.... & & 0.105 & 0.113 & 0.138 & & 0.764 & & 0.445 \\
\hline Sikap - Keper.... & & 0.125 & 0.124 & 0.124 & & 1.010 & & 0.313 \\
\hline Sikzp -> Loyali.... & & 0.139 & 0.144 & 0.121 & & 1.151 & & 0.250 \\
\hline
\end{tabular}

Sumber : data diolah

\section{Pengujian Hipotesis}

\section{Pengujian Hipotesis H1}

Terdapat pengaruh yang tidak signifikan dari variabel sikap yang baik terhadap variabel loyalitas, hal ini dapat dilihat dari nilai pengaruh $P$-value $>0,05$ dan $T$-statistics $<1.96$. Hasil temuan ini tidak sesuai dengan penelitian dari Astrachan et al. (2002). "NonFamily CEO's in the Family Business : Connecting Family Values to Business Sucess" dimana sikap tidak termasuk dalam pertimbangan loyalitas pada pemilik generasi pertama, perbedaan ini terjadi melihat dari sampel yang digunakan pada penelitian, dimana sampel yang dipakai pada penelitian ini adalah pemilik bisnis generasi pertama, sedangkan penelitian dari Astrachan et al. (2002) menggunakan sampel yang cukup bervariasi dari pemilik usaha generasi ke-1 , generasii ke-2 dan generasi ke-3, namun jumlah terbanyak sampel yang dambil adalah pemilik bisnis pada generasi ke-2. Sedangkan pada penelitian ini sampel terbanyak adalah pada generasi ke-1 (pertama).

Hasil penelitian yang dilakukan pun berbeda hasilnya dengan hasil penelitian dari Chua et al. (2003) dalam temuannya yang berjudul Succession and nonsuccession concerns of family firms and agency relationships with nonfamily managers". Hasil penelitian pada jurnal tersebut 
mengungkapkan adanya keterkaiatan yang positif dari sikap yang baik dengan loyalitas karyawan. Melihat hal seperti ini peneliti menduga adanya perbedaan dari jumlah karyawan yang dimiliki, pada penelitian Chua et al. (2003) sampel yang terbanyakmemiliki karyawan pada skala $50-$ 100 orang. Berbeda dengan pada penelitian yang dilakukan dimana sampel pemilik bisnis hanya memiliki karyawan yang berjumlah 10 - 50 orang. Sesuai dengan teori agensi karyawan yang dimiliki, poin sikap yang baik memiliki hubungan dengan loyalitas karyawan.

\section{$\underline{\text { Pengujian Hipotesis H2 }}$}

Terdapat pengaruh yang tidak signifikan dari variabel sikap terhadap variabel kepercayaan, hal ini dapat dilihat dari nilai pengaruh $P$-value $>0,05$ dan $T$-statistics $<1.96$. Hasil penelitian ini bertentangan dengan hasil temuan dari McCollom (1992) yang berjudul "The Ownership Trust and Succession Paralysis in the Family Business". dimana sikap yang baik dari para karyawan justru bukan menjadi pertimbangan dari pemilik bisnis generasi pertama dalam memberikan kepercayaan dan suksesi. Melihat perbedaan ini peneliti menduga adanya perbedaan pada sampel yang digunakan. Penelitian yang dilakukan oleh McCollom (1992) tidak membedakan sampel pada pemilik bisnis, namun pada penelitian ini peneliti hanya membatasi pada generasi pertama. Perbedaan pemilihan sampel ini diduga akan menjadi perbedaan pandangan pemilik bisnis.

\section{Pengujian Hipotesis $\mathrm{H} 3$}

Terdapat pengaruh yang signifikan dari variabel integritas terhadap variabel loyalitas , hal ini dapat dilihat dari nilai pengaruh $P$ value $<0,05$ dan $T$-statistics $>1.96$. Hasil penelitian ini sejalan dengan Hall et al. (2008) dalam temuanya yang berjudul "Professional Management in Family Businesses: $\quad$ Toward an Extended Understanding Dimana integritas masih menjadi penliaian loyalitas bagi pemilik bisnis generasi pertama. Melihat hasil penelitian ini walaupun adanya perbedaan sampel tidak membedakan pandangan dari pemilik bisnis untuk menilai karyawan yang loyalitas dari integritas. Para pemilik bisnis melihat para karyawan yang loyal dengan berbagai pertimbangan dan salah satunya adalah dari integritas yang dimiliki oleh karyawan.

\section{$\underline{\text { Pengujian Hipotesis H4 }}$}

Terdapat pengaruh yang signifikan dari variabel integritas terhadap variabel kepercayaan, hal ini dapat dilihat dari nilai pengaruh $P_{-}<0,05$ dan T-statistics $>1.96$. dari Arnoff and Ward (2000) "More than family: Non-Family Executives in the Family Business," hasilnya intergtias dan kepercayaan berpengaruh positif terhadap suksesi. Hasil temuan ini semakin memperkuat hubungan dari variabel integritas terhadap variabel kepercayaan, dimana para pemilik usaha mempertimbangkan karyawan yang dapat dipercaya dalam menjalankan tugas dari integritas para karyawan yang bekerja.

\section{Pengujian Hipotesis H5}

Terdapat pengaruh yang tidak signifikan dari variabel loyalitas terhadap variabel suksesi, hal ini dapat dilihat dari nilai pengaruh $P$-value $>0,05$ dan $T$-statistics $<1.96$. Hasil temuan ini tidak sesuai dengan penelitian dari Diamond (2006) pada temuanya yang berjudul "Finding Success through succession planning. Security Management". Dan penelitian dari Astrachan et al. (2002) yang berjudul "Non-Family CEO's in the Family Business : Connecting Family Values to Business Sucess. Yang hasil penelitianya keduanya mengungkapkan adanya hubungan dari loyalitas terhadap suksesi yang bernilai positif.Namun perbedaan hasil penemuan menimbulkan dugaan dari pemilihan sampel dimana sampel yang diambil pada penelitian ini kebanyakan pemilik perusahaan yang memliiki umur usaha mulai dari 1- 5 tahun. Melihat kondisi usaha yang masih maka masih belum memiliki karyawan yang dapat dikatakan "loyal". Sehingga mungkin pada penelitian 
selanjutnya akan diperbanyak kembali sampel yang ada untuk memperkuat dugaan apakah ada hubungan dari loyalitas dengan suksesi .

\section{Pengujian Hipotesis H6}

Terdapat pengaruh yang signifikan dari variabel kepercayaan terhadap variabel suksesi, hal ini dapat dilihat dari nilai pengaruh $P$-value $<0,05$ dan $T$-statistics $>1.96$. Hasil temuan ini mendukung hasil penelitian dari Ward (2000) yang berjudul More than family: Non-Family Executives in the Family Business" dan McCollom (1992) yang berjudul "The Ownership Trust and Succession Paralysis in the Family Business." yang mengungkapkan hasil penelitian dari keduanya adanya hubungan dari kepercayaan terhadap suksesi yang bernilai positif. Dapat dikatakan bahwa dasar dalam mempertimbangkan suksesi dapat diliaht dari kepercayaan yang diberikan kepada pemilik usaha kepada karyawanya.

\section{SIMPULAN DAN SARAN}

\section{Simpulan}

Bedasarkan hasil dari penelitian yang dilakukan maka didapatlah simpulan sebagai berikut :

1. Variabel sikap yang baik tidak memiliki pengaruh yang signifikan terhadap variabel Loyalitas. Pemilik usaha merasa sikap yang baik yang dimiliki oleh seorang bawahan/karyawan tidak cukup kuat untuk mendorong mereka menjadi loyal terhadap perusahaan.

2. Variabel sikap yang baik tidak memiliki pengaruh yang signifikan terhadap variabel Kepercayaan. Pemilik usaha menganggap untuk mempercayai seorang karyawan tidak cukup kuat hanya bedasarkan dari sikap yang dimiliki karyawan tersebut.

3. Variabel Integritas memiliki pengaruh yang signifikan terhadap variabel Loyalitas. pemilik usaha menganggap integritas sebagai faktor yang mendukung loyalitas karyawan.
4. Variabel Integritas memiliki pengaruh yang signifikan terhadap variabel Kepercayaan. Pemiik usaha merasa bahwa integritas menjadi faktor-faktor yang mendukung untuk mempercayai seorang karyawan.

5. Variabel Loyalitas tidak memiliki pengaruh yang signifikan terhadap variabel Suksesi. Pemilik usaha tidak selalu memilih calon penerus yang bedasarkan dari loyalitas terhadap perusahaan.

6. Variabel Kepercayaan memiliki pengaruh yang signifikan terhadap variabel Suksesi. Pemilik usaha merasa bahwa untuk memilih calon suksesor maka ia akan memilih calon suksesor yang bisa dia percaya.

\section{Saran}

Beberapa saran yang diberikan oleh para peneliti adalah sebagai berikut :

1. Hasil dari penelitian ini memiliki temuan yang menarik untuk dikembangkan untuk menggali lebih dalam faktor suksesi misalnya, loyalitas tidak berpengaruh dalam suksesi, dari hal ini dapat didapat bahwa loyalitas karyawan belum cukup untuk meyakinkan pemilik usaha dalam penentuan suksesi berebeda dengan rasa kepercayaan yang bernilai positif yang dapat membuat pemilik usaha yakin memberikan suksesi. Saran selanjutnya bagi peneliti dapat mengembangkan kembali faktor- faktor apa sajakah yang berpengaruh dalam suksesi, antara lain :

a. Penelitian selanjutnya dapat menggunakan sampel yang lebih besar untuk menguatkan hasil temuan yang ada.

b. Penelitian selanjutnya dapat menggunakan sampel yang berbeda (sudut pandang generasi ke-2, generasi ke-3, atau generasi ke-4) untuk menguatkan hasil temuan yang ada. 
c. Penelitan dapat meneliti lebih lanjut dari sudut pandang yang berbeda, yaitu pada Family Business Enterprise (FBE) dimana perusahaan yang dimiliki dan dikelolah oleh keluarga pendirinya.

\section{DAFTAR PUSTAKA}

Aronoff,C.E., and Ward, J.L. 2000. More than family : Non-Family Executives in the Family Business, FB Leadership Series. Marietta, GA.US

Astrachan, Keyt, Lane, and Yarmalouk. 2002. "Non-Family CEO's in the Family Business : Connecting Family Values to Business Sucess", Proceedings FBN-ifera Helsinki, 1114th of Sept 2002, pp.183-19

Barnes, L. B., \& Hershon, S. A. 1989. Transferring Power in the Family Business. Family Business Review, 2(2), 188-202.

Beckhard, R., and Dyer, W. "Managing Continuity in the Family-Owned Business." Organizational Dynamics, 1983b, 12, 5-12.

Chua, J., Chrisman, J., \& Sharma, P. 2003. Succession and nonsuccession concerns of family firms and agency relationships with nonfamily managers. Family Business Review, 16(2), 89-107.

Churchill, N. C, and Lewis V. L. "The Five Stages of Small Business Growth." Harvard Business Review, 1983, 61, 30-51.

Diamond, A. 2006. Finding Success Through Succession Planning. Security Management, 50 (2),36-39

Baer, Greg. 2007. Real Love in the Workplace: Eight Principles for Consistently Effective Leadership in Business. GA: Blue Ridge Press, Rome
Beckhard, R., and Dyer, W.G.,Jr. 1983 "Managing Continuity in the FamilyOwned Business, "Organizational Dynamics.,12(1),5-12.

Dussault, Marc R. 2008. What is a Family Business? Retrieved 20 September 2013

Farquhar, K. A. 1989. "Employee Responses to External Executive Succession: Attributions and the Emergence of Leadership.

Gilmore, R.N. and J.E. McCann III. 1983. "Designing Effective Transitions for new Correctional Leaders", In J.W. Doig (ed.) Criminal Corrections: Ideals and Realities, Lexington, $\mathrm{Va}$ : Lexington Books

Gordon, G. E., and Rosen, N. "Critical Factors in Leadership Succession." Organizational Behavior and Human Performance, 1981, 27, 227-254harv

Hall, Anika, Mattias Nordqvist. 2008. Professional Management in Family Businesses: Toward an Extended Understanding. Family Business Review. vol. XXI, no. 1, March, pp. 51-68.

Handler, W. C. "Succession in Family Firms: A Mutual Role Adjustment Between Entrepreneur and Next-Generation Family Members." Entrepreneurship: Theory and Practice, 1990, 15(1), 3751.

Handler, W. C. "The Succession Experience of the Next-Generation." Family Business Review, 1992, 5(3), 283307Handler, W. C. "The Succession Experience of the Next-Generation." Family Business Review, 1992, 5(3), 283-307

Harveston, Paula D., Peter S. Davis and Julie A. Lyden. 1997. Succesion Planning in family Business: The Impact of Owner Gender. Family Business Review. Dec v10 i4 p373, Family Firm Institute, Inc. 
Kets de Vries, M.F.R. "The Dark Side of Entrepreneurship." Harvard Business Review, 1985, 63, 160-167

Lansberg, I. 1999. Succeeding Generations: Realizing the Dream of Families in Business. Boston, MA: Harvard Business School Press.

Levinson, H. "Consulting with the Family Business: What to Look For, What to Look Out For." Organizational Dynamics, 1983, 12, 71-80.

Longenecker, J. G., and Schoen, J. E. "An Empirical Investigation of Pre-Entry Socialization of Successors for Leadership in Family-Controlled Businesses." Management Perspectives on Organizational Effectiveness. Proceedings of the Southern Management Association meetings, 1975.

Longenecker, J. G., and Schoen, J. E. "Management Succession in the Family Business." Journal of Small Business Management, 1978, 16, 1-6.

McCollom, M. "The Ownership Trust and Succession Paralysis in the Family Business." Family Business Review, 1992, 5(2), 145-160.

Poza, Ernesto J. 2007. Family business, 2nd edition. United States of America: Thomson South -Western.

Rothwell William J. 2010, Effective Succession Planning: Ensuring Leadership Continuity and Building Talent from Within, 4th Edition. New York: Amacom

Royer, Susanne, Roland Simons, Britta Boyd, and Alannah Farrerty. 2008. Promoting Family: A Contingency Model of Family Business Succession. Family Business Review. vol. XXI, no. 1, March, pp. 15-30.

Schein, E. H. "The Role of the Founder in the Creation of Organizational Culture." Organizational Dynamics, 1983, 12, 13-28.
Sugiyono, 2012. "Memahami Penelitian Kuantitatif". Bandung : Alfabeta

Zulfikar, Mochammad Reza. 2004. Analisis Pengaruh Faktor Nilai-nilai Utama Karyawan terhadap Budaya Perusahaan. 
